\title{
The use of secondary build-up in historical fabric based on the donjon of Kłodzko Fortress
}

\author{
Piotr Gleń ${ }^{1, *}$, Karol Krupa ${ }^{1}$ \\ ${ }^{1}$ Lublin University of Technology, Faculty of Civil Engineering and Architecture, Nabystrzycka 40 st. \\ 20-618 Lublin, Poland
}

\begin{abstract}
Basing on the secondary warehouses in the donjon of Kłodzko Fortress, the authors of this paper discuss the subject of interference in the historical structure, as well as the opportunities that comes with such inclusion. They analyse the possibilities to use the space incorporated into the existing fabric of a historical object on the basis of a building survey. This article scrutinises the problem of interference in a very particular military object and all related issues that might arise in this area. Postindustrial warehouses are located in the donjon, which is the last ring of defence. These secondary buildings touch two interesting issues: the introduction of the new function to the whole complex and, on the other hand, the interference in the original form of the ramparts situated over casemated halls of the courtyard. To address this problem, the authors analyse the existing structure for its functionality, usability and design, presenting its advantages, disadvantages and perspectives in the context of the whole complex of Kłodzko Fortress. The fortress is an interesting tourist spot because of its location in the scale of the city and the Kłodzko Valley region. It might be considered as a nodal point for the touristic attractions of the area.
\end{abstract}

\section{Introduction}

Dynamic military development is the reason that currently existing defensive structures can't keep up with the arms industry boom, which might be observed during the last couple of decades. The former military buildings become the relics of the past times. They often dominate their surroundings. A perfect example of this phenomenon is Kłodzko Fortress. It is the most dominant and characteristic element overlooking the city from the natural elevation. The present world political situation made such objects attractive for tourists. Therefore, they should be adapted in the most optimal way to comply with the current usage standards. Fast development of tourism observed over the last years has had an impact on the opportunities to revitalise forgotten historical buildings. Today most foreign tourists who visit the area of Kłodzko come from Germany. This group of tourists requires a higher standard of service and better spatial and visual reception of such objects. The most active group working dynamically on revitalization of the military buildings is currently Polish Society of Friends of Fortification. It cooperates with Polish technical

* Corresponding author: p.glen@pollub.p1 
universities. Thanks to such relations, it is possible to make different kind of building surveys and proposals of spatial development and revitalisation of both the historical buildings and their surroundings [1]. New function in building becomes a driving force for future development [2]. Among various buildings, not only military, there is a problem with the development of objects for a new utility function. Such objects include sacred or postindustrial buildings, which is associated with their difficult cubature [3].

\section{Historical background}

Kłodzko city is situated in dolnośląskie voivodship, kłodzko county in north-east part of the Kłodzko Valley. The city development is connected with its location in the Valley of Nysa Kłodzka River. Initially, in the place of the currently existing fortress there was a medieval castle built in the $14^{\text {th }}$ century and then rebuilt in the $16^{\text {th }}$ century $[4,5]$. The urban layout of the castle consisted of a complex of buildings with courtyards on an irregular plan. It was made on the basis of the cascade spatial layout following the shape of the hill, where it was located. In 1622, the siege of the city with artillery fire was the cause of the modernisation of the fortifications and the castle itself [6]. After the seizure of the castle by gen. Gerhard Cornelius Walrave on the request of Frederic II, the reconstruction of the fortress has begun. During this period, the new plan of fortifications was developed and a new Owcza Góra fortress was located on the adjacent hill [7]. Over the years, the defence needs of the fortress have been changing leading to change of its shape and structure. In 1760, the fortress was taken over by the Austrians and the donjon was built as the last line of fortifications. Then due to intensive military development the fortress was starting to loose its military importance. During World War II it was used as a SS headquarters and a prison [8]. Then the fortress was constantly changing its function. In 1944, it was an arms factory of AEG from Łódź [9]. Since that time until 1957, the building was in the hands of a local army unit based in the fortress. In the following years it was used for different business activities, e.g. to produce wine [10]. In 1960, it was entered into the register of monuments and was made available for the tourists [11].

\section{The Donjon}

The donjon of the Kłodzko Fortress is definitely the most characteristic point of all fortifications. It is the last defence bastion and at the same time the highest point of the Main Fortress (Fig. 1). This name is a bit uncommon but it refers to the original $14^{\text {th }}$ century castle, which was at this spot before. However, this name has been naturally adopted and it functions to this day. It was based on the ixodial ground-plan with three levels of casemats. Western and southern part has only one level [12].

The Main Fortress is situated on the top of natural elevation on bedrock. Bricking stonewalls are intertwined with stonewalls and brick dome covered with the ramparts. External walls have rifle and artillery battlements. The façade from the internal side of the courtyard has rectangular window and door openings with many secondary openings made over the years when the fortress was used for many different purposes. Other remarkable elements are two big entrance gates crowned with semi-circular arcs, which lead to the courtyard. During World War II their width was adapted to fulfil changing military needs for example to enable driving in the donjon area of the heavy artillery equipment. Internal façade of the courtyard has simple architectonic form enriched only with characteristic draining elements of the ramparts in the form of ordinary gargoyles without any decorations. This was mainly because of the purely functional military role of the building. That is why all the elements of the fortress are simple and durable. 


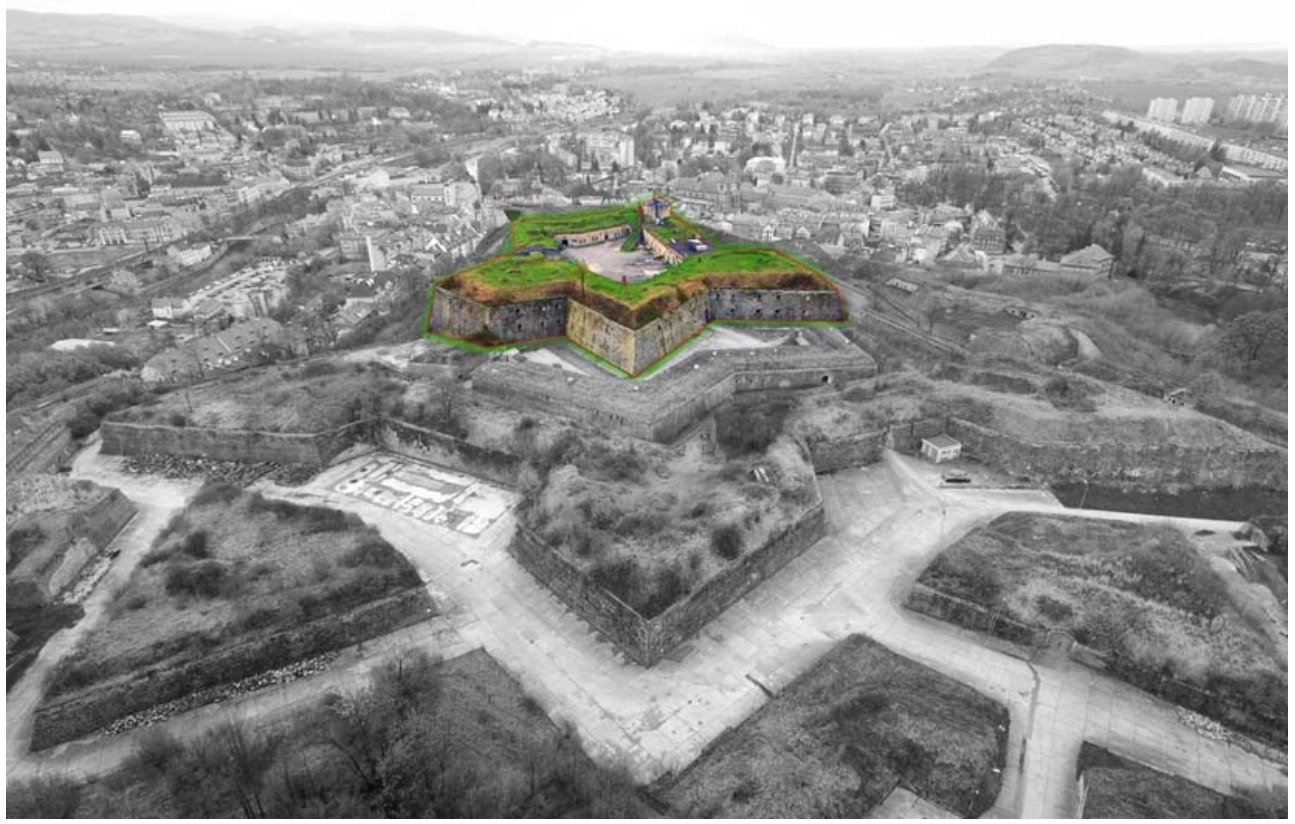

Fig. 1. The view on the Donjon - the localization in the scale of the Main Fortress - own elaboration.

\section{The survey of the complex with the method of terrestrial laser scanning}

Laser scanning is currently one of the most accurate methods of measurements used for the development of the documentation of already existing buildings. Soon it may become the standard measurement method of historical buildings. [13] Scanning enables to make fast spatial building condition survey. The short time of measurement is not the only advantage of this building condition survey method in this case. With the use of gathered spatial data it is possible to create a three-dimensional model of an object including complex structures and details [14]. Nevertheless, the key advantage of laser scanning method is that obtaining data with it is fast and easy.

From 2016, scientists from the Lublin University of Technology have conducted building condition and conservation surveys in the Main Fortress in Kłodzko. With the use of Leica C10 scanner (Tab. 1.) (Fig. 2.a) very detailed survey of fortress complex is made. This scanner records information in the form of point clouds with the use of sent laser beam (Fig. 2.b) reflected from the scanned object. Then gathered data are processed to obtain the following products: filtered and oriented point clouds, orthoplans of the object, vector models of the surface, architect reports (projections, cross sections, elevations), contour models, hypsometric models, 3D models [15]. 
Table 1. Technical specification of the 3D scanner Leica C10

Source: www.leica-geosystems.pl [access 22.03.2018].

\begin{tabular}{|c|c|}
\hline \multicolumn{2}{|r|}{ TECHNICAL SPECIFICATIONS } \\
\hline \multicolumn{2}{|r|}{ Accuracy of the single measurement } \\
\hline Situation* & $6 \mathrm{~mm}$ \\
\hline Distance* & $4 \mathrm{~mm}$ \\
\hline Angle (horizontal/vertical) & 60/60 microradians (12"/12”) \\
\hline Accuracy of modelled surface & $2 \mathrm{~mm}$ \\
\hline Shields scanning & Standard deviation $-2 \mathrm{~mm}$ \\
\hline \multicolumn{2}{|r|}{ LASER SCANNER } \\
\hline Type & Pulse, own layout \\
\hline Colour & Green, wave length $532 \mathrm{~nm}$ \\
\hline Laser class & 3R (IEC 60825-1) \\
\hline Range & $\begin{array}{l}300 \mathrm{~m} \text { by } 90 \% \text { of albedo; } 134 \mathrm{~m} \text { by } 18 \% \text { of albedo, (minimum } \\
\text { range } 0.1 \mathrm{~m} \text { ) }\end{array}$ \\
\hline Speed of scanning & Up to $50,000 \mathrm{pt} / \mathrm{s}$, maximum speed, temporary \\
\hline \multicolumn{2}{|r|}{ Scanning resolution } \\
\hline Size of the laser dot & $\begin{array}{l}\text { From 0-50 m: } 4.5 \mathrm{~mm} \text { (FWHH test); } \\
7 \mathrm{~mm} \text { (Gauss' test) }\end{array}$ \\
\hline Distance between the points & $\begin{array}{l}\text { Selected horizontal and vertical, minimum distance, } 1 \mathrm{~mm} \text {, } \\
\text { in all range, single points }\end{array}$ \\
\hline \multicolumn{2}{|r|}{ Field of vision } \\
\hline Horizontally & $360^{\circ}($ maximum $)$ \\
\hline Vertically & $270^{\circ}($ minimum $)$ \\
\hline Aiming/orientation & Free from parallax, integrated camera with zoom \\
\hline Scanning optics & $\begin{array}{l}\text { Mirror turning vertically or scanner platform turning } \\
\text { horizontally; Smart X-Mirror }{ }^{\mathrm{TM}} \text { mirror turns automatically } \\
\text { shortening scanning time }\end{array}$ \\
\hline Laser plummet & $\begin{array}{l}\text { Laser class: } 2 \text { (IEC } 60825-1 \text { ) } \\
\text { Accuracy of centring: } 1.5 \mathrm{~mm} \text { at the height of } 1.5 \mathrm{~m} \\
\text { Diameter of laser dot: } 2.5 \mathrm{~mm} \text { at the height of } 1.5 \mathrm{~m} \\
\text { The possibility to turn on/turn off }\end{array}$ \\
\hline
\end{tabular}
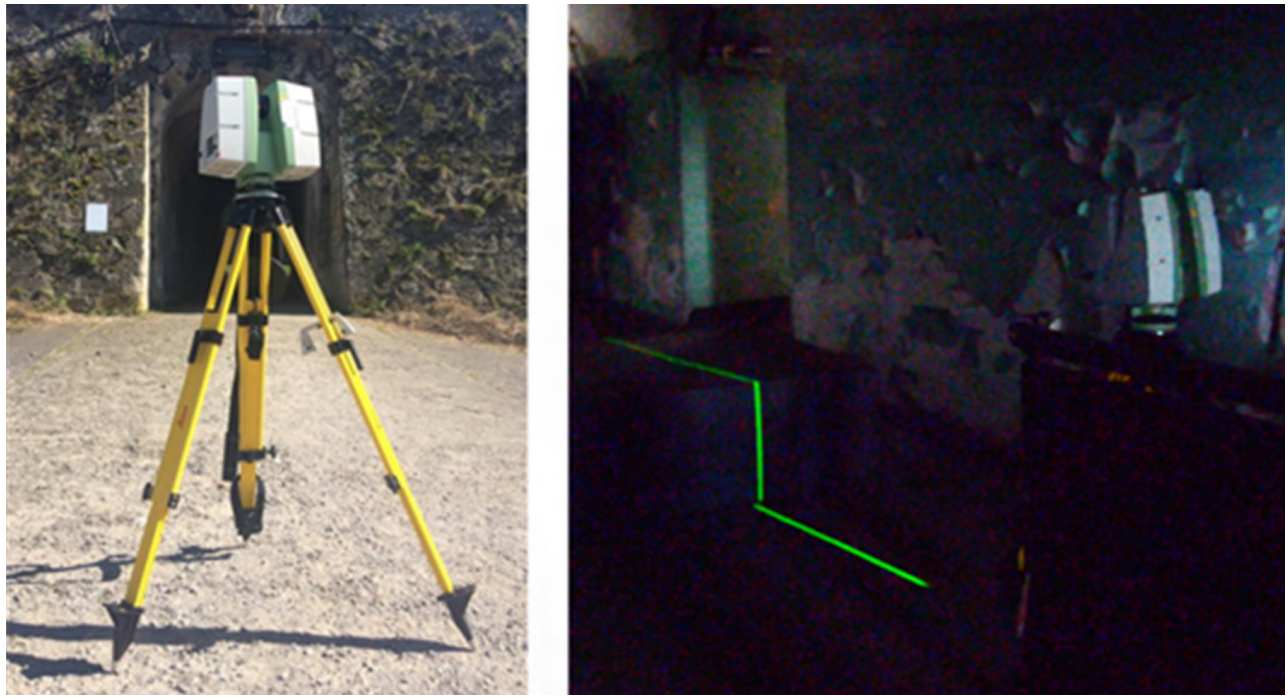

Fig. 2. Leica C10 scanner - own elaboration. 
The first stage of the scanning of the donjon of the Kłodzko Fortress consisted of 23 measurement stands (outside of measured cubature) with scanner and 45 stands in casemates of the building. The number of measurement points resulted from the range of the laser scanner beam (the greater the distance between the points, the less accurate the measurement) and the characteristics of the building (numerous creases, bay windows, architectonic details). It is worth noting that if we decrease the distance between the points where we put the scanner, we will achieve greater accuracy of the scan.

The next stage is the import of obtained measurement to Leica Cyclone 7.4.1 program to connect separate stands into one three-dimensional model made out of the points cloud (Fig. 3).

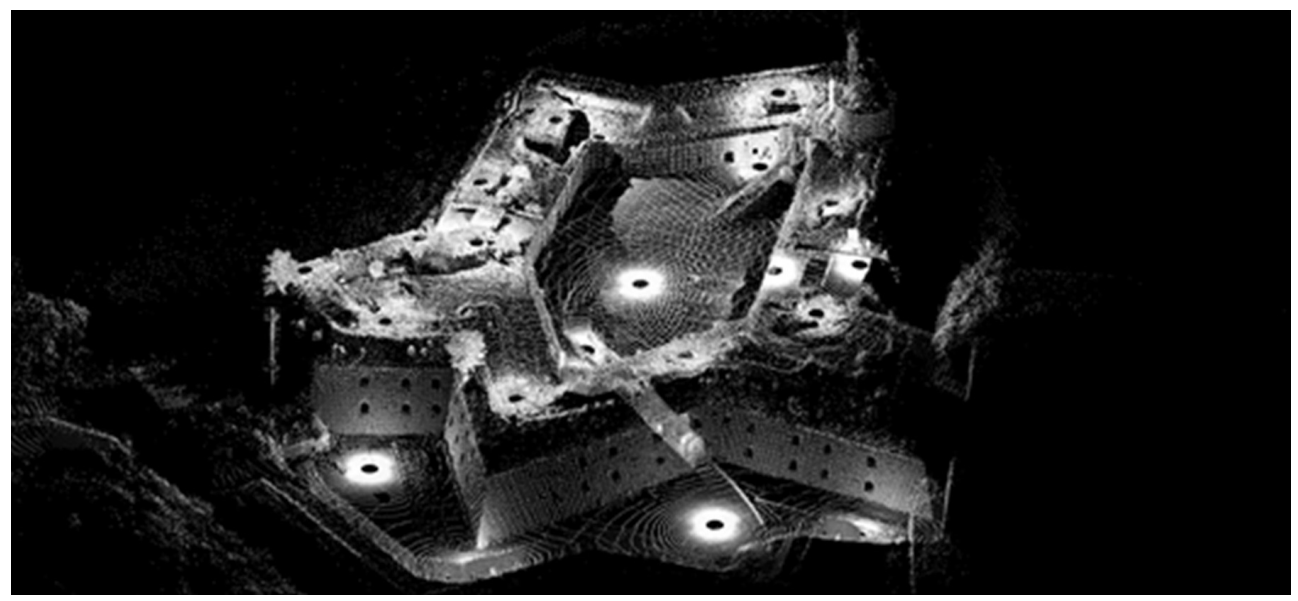

Fig. 3. Points cloud from connected stands in Leica Cyclone 7.4.1 program - own elaboration.

After the first stage of scanning in 2017, three-dimensional model of the donjon was developed (Fig. 4 and 5) with surrounding walls, passages and also casemates. Thanks to this survey method it is possible to determine precisely the thickness and height of the walls, as well as the thickness of the ramparts over the halls. Traditional measurement methods may be to some degree imprecise because of the characteristics of the architectural form of the said fortress. The Kłodzko Fortress was built at the top of a natural elevation on bedrock, which it difficult location for a thorough survey. Other elements that may hinder measurements are ramparts, thick walls and several underground corridors. In this case it was possible to use archive materials, but it is worth pointing out that the object was partly degraded over the years due to state of war or other damages caused e.g. by overgrowing wild greenery. Part of the underground corridors was buried, like for example Poterna (the tunnel used to transport arms from the city in a cable car), which lead to the big tongs from the side of the city. 


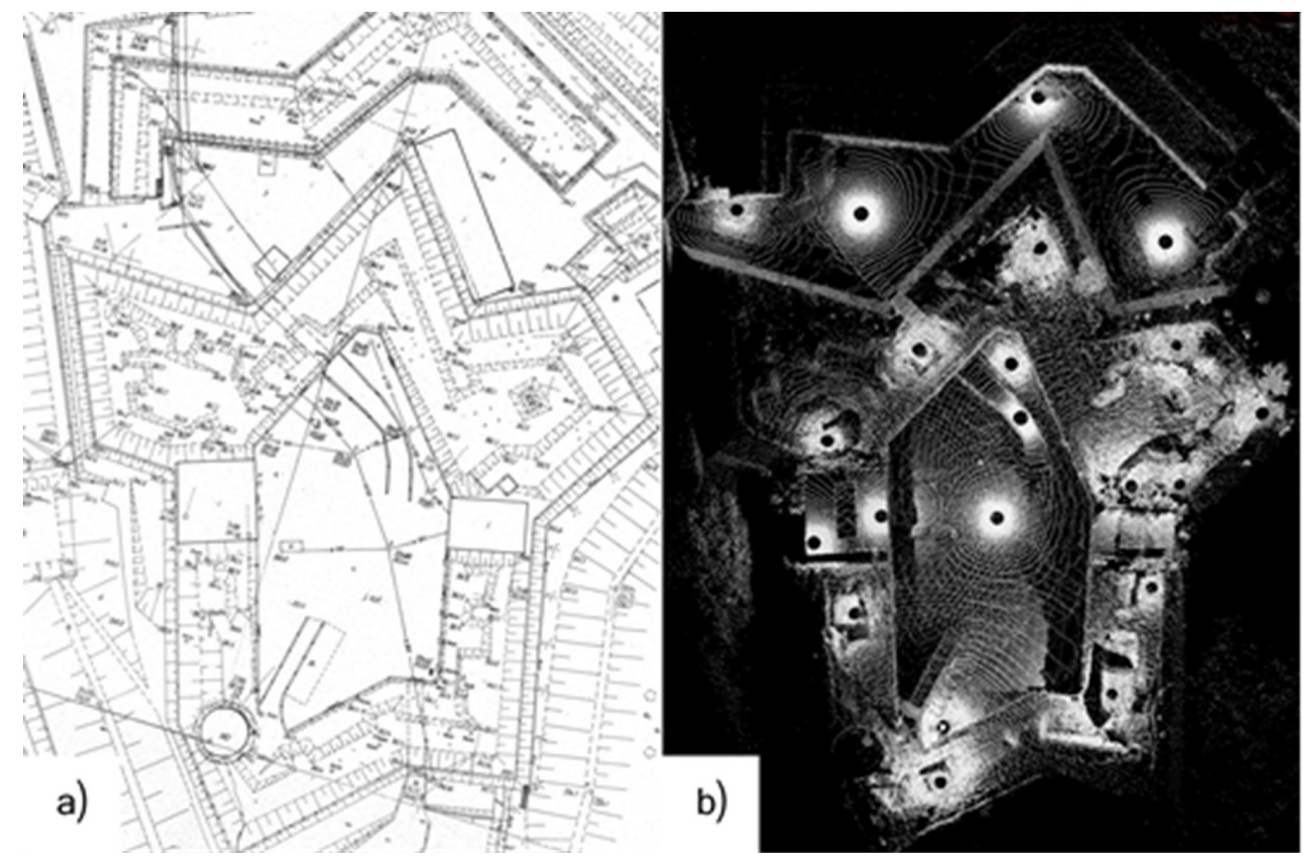

Fig. 4. The comparison of the basic map (a) and 3D scanning (b) - own elaboration.

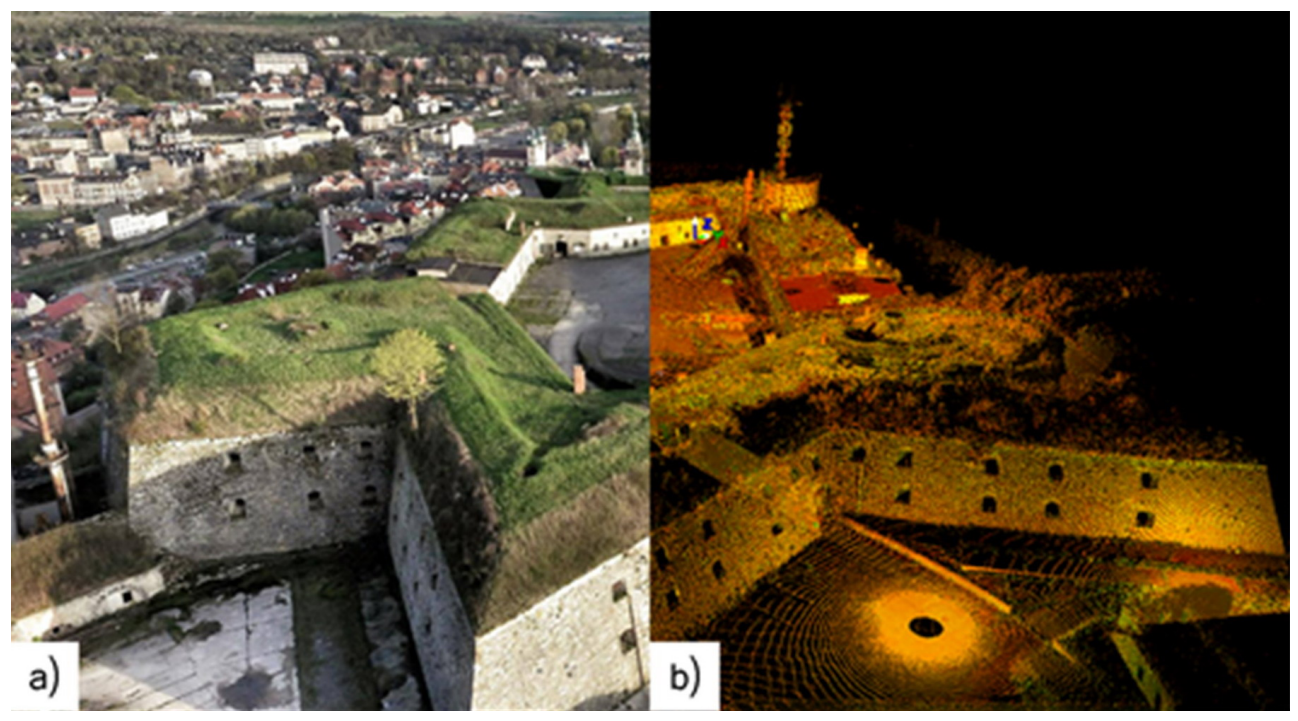

Fig. 5. The comparison of the picture of the object made with the use of a drone (a) with 3D scanning (b) - own elaboration. 


\section{Warehouses}

Currently there are two secondary halls - former warehouses on the courtyard of the donjon (Fig. 6 and 7).

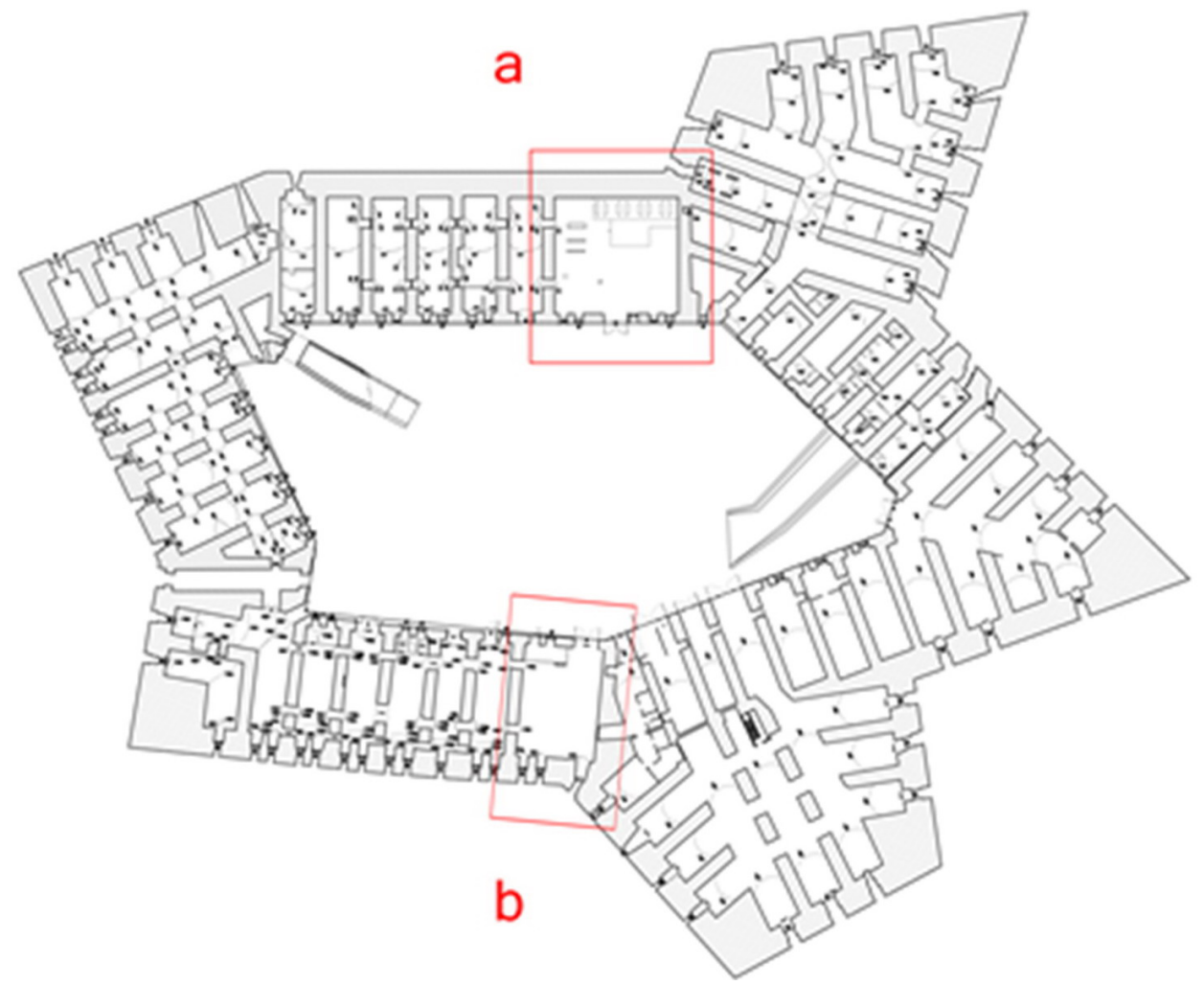

Fig. 6. The location of post-industrial warehouses in the donjon.
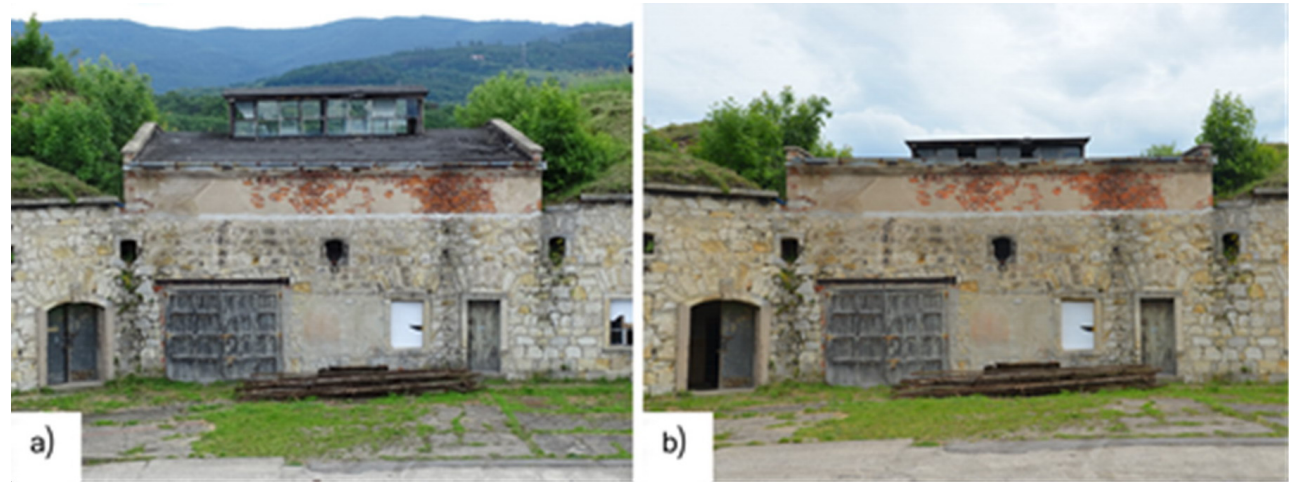

Fig. 7. The view on the secondary post-industrial warehouses from the side of the courtyard.

The incorporation of the warehouses into the space of the courtyard and the outline of the ramparts of the donjon is very aggressive. It interferes greatly with the structure of historical fabric of the building. However, it is possible to find also some positive aspects of this integration. Damaging of the part of the façade of the donjon to build industrial 
warehouses made is possible to adapt this complex to have different functions. Because of their characteristics, the rooms in the fortress are not adjusted to fulfil the current design standards. The open space inside the existing halls might be used in order to adapt them in many different ways easier than other spaces of the fortress. Not only is the greater useful floor area of the space important here, but also the possibility to use finishing materials other than original ones. Basic conservatory doctrine says that in order to introduce new element in historical buildings it is necessary to use new materials to clearly differentiate new elements from secondary ones. What is more, technical condition of these elements excludes their further use (Fig. 8).
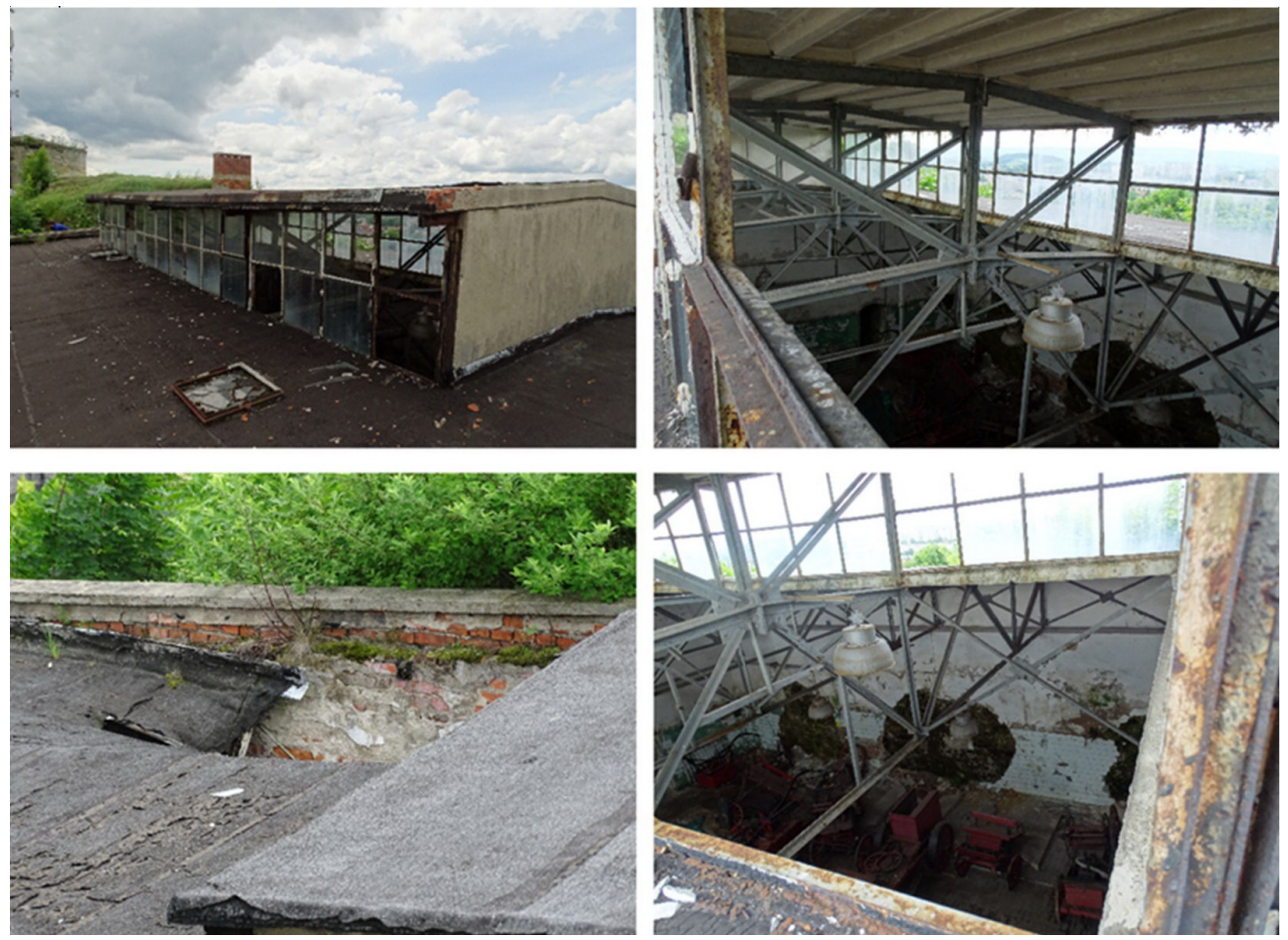

Fig. 8. The view of the secondary post-industrial warehouses - current shape.

During research in the Main Fortress, the students of the Lublin University of Technology made building survey and have studied its technical condition. It was the basis of the master's thesis "Revitalization of Kłodzko Fortress with the adaptation of the dojnon». The paper has presented the subject of the revitalization of the donjon (Fig. 9). The authors proposed adaptation of the space of former warehouses for exhibition halls and restaurant. 


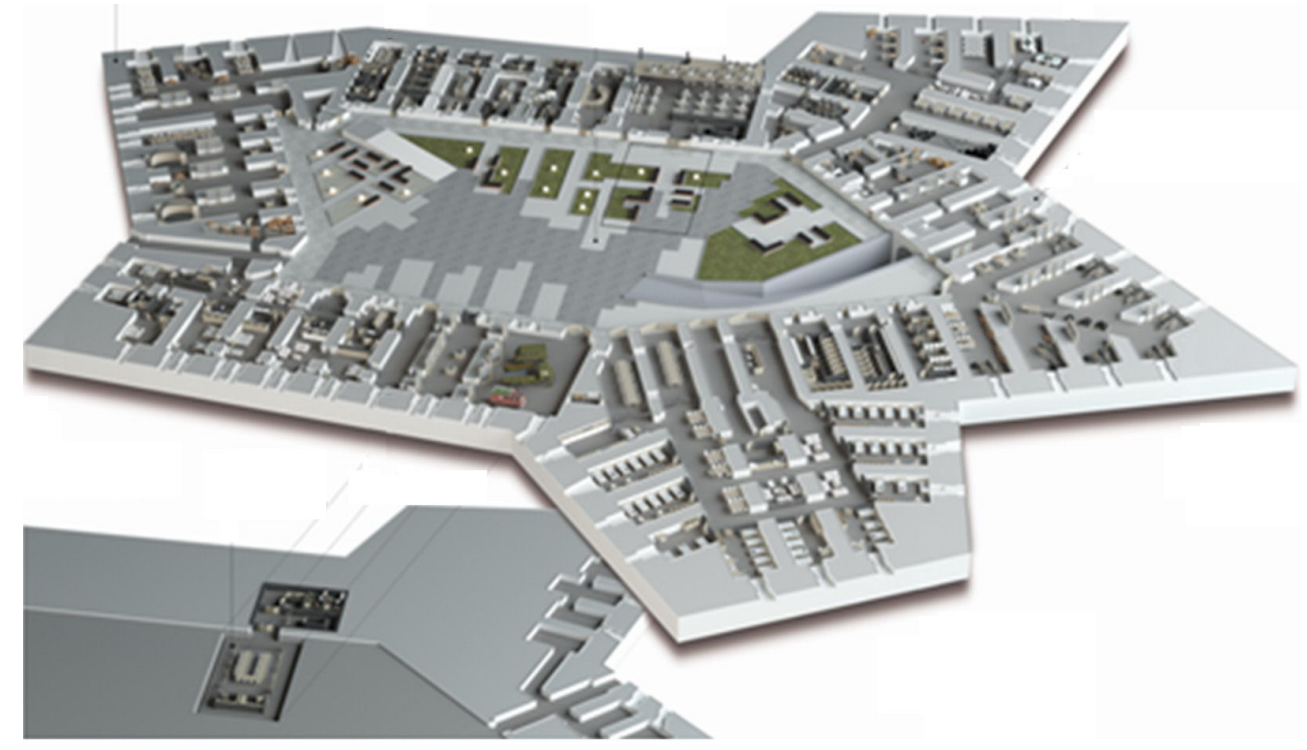

Fig. 9. The proposition to adapt the donjon included in the master's thesis «Revitalization of the Kłodzko Fortress with the adaptation of the dojnon» made in Faculty of Civil Engineering and Architecture in Lublin University of Technology in 2017 - elaborated by K. Drobek, K. Tkaczyk, K. Knap.

The authors of this paper not only present functional solutions, but also propose the final look of the adapted halls with the use of new materials on the façade which complete historical fabric of Kłodzko Fortress (Fig. 10). The diploma paper was written on the basis of the materials coming from 3D scanning and architectural recordings to assess the technical condition of the building made by the scientists of Lublin University of Technology in 2016-2017.

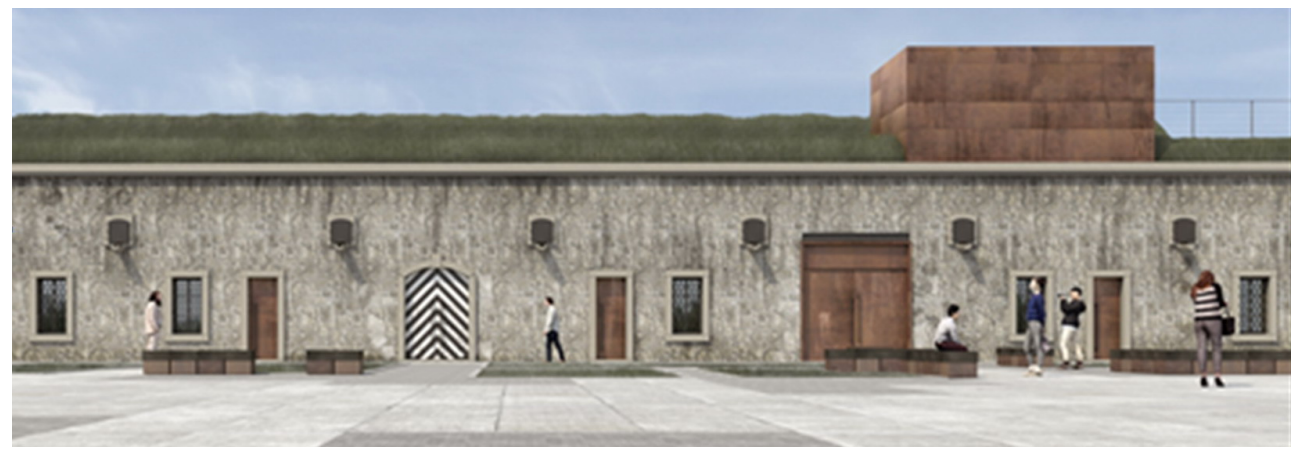

Fig. 10. The proposition to adapt the warehouses in the donjon included in the master's thesis «Revitalization of the Kłodzko Fortress with the adaptation of the dojnon» made in Faculty of Civil Engineering and Architecture in Lublin University of Technology in 2017 - elaborated by K. Drobek, K. Tkaczyk, K. Knap. 
The revitalization itself is difficult and the introduction of new elements to this kind of structure is very complex and problematic. That is why it is necessary to use all aggressive elements, which already irreversibly violated the monument from the architectural point of view (uncoordinated greenery, cubature objects introduced contrary to the conservation doctrine). Implementation of the new functions other than the original ones aims at preservation of the historical objects that are priceless witnesses of the past. New function makes it possible to protect the fortress, improve the economical situation of the building and impact all surrounding area.

\section{Conclusion}

After the analysis of economical situation and social needs, basing on conducted research of technical condition and building survey documentation made with the use of 3D scanning of the donjon, the authors of the paper conclude that adaptation of this type of space for new functions is possible or even necessary. What is more, the damages of the historical fabric of the building, which appeared over the years of its use, may facilitate solutions and integration of a new structure in the complex. It also made it easier to adapt it to current design standards.

\section{References}

1. P. Molski, Fortyfikacje jako atrakcje turystyczne (2003)

2. P. Gleń, A. Jarocka-Mikrut, CEER 19, 13 (2015)

3. A. Jarocka-Mikrut, P. Gleń, CEER 21, 27 (2016)

4. B. Guerquin, Zamki Śląskie (1957)

5. T. Broniewski, Śląsk w zabytkach sztuki (1963)

6. E. Triller, Rocznik Ziemi Kłodzkiej 1958, III (1959)

7. G. Bukal, Niderlandyzm w sztuce polskiej (2000)

8. T. Jędrysiak, A. Mikos von Rohrscheidt, Militarna turystyka kulturowa, PWE (2011)

9. www.dawnekłodzko.pl (access 26.03.2018)

10. www.zamkipolskie.pl (access 26.03.2018)

11. Decision KL-V-1/61/30 of 13.05 .1960 of entering the building to the monuments register

12. C. Głuszek, M. Górski, P. Kinsner, Twierdza Kłodzko. Ocena zagrożeń zabytkowych struktur i stanu wybranych pomieszczeń, II (2007)

13. R. Zapłata, BiA 14, 165 (2015)

14. K. Michałowska [ed.], Modelowanie i wizualizacja danych 3D na podstawie pomiarów fotogrametrycznych i skaningu laserowego (2015)

15. B. Mitka, PTFiT 17b (2007) 